\title{
Social and Educational Effects (Dominants) in Schoolchildren' Ethno-cultural Education
}

\author{
Liudmila V. Kuznetsova \\ Tatyana N. Petrova \\ Vladimir N. Ivanov \\ Galina G. Tenyukova \\ Igor V. Kozhanov \\ Natalya S. Morova \\ Sergey P. Yakovlev \\ Chuvash State Pedagogical University named after I.Ya.Yakovlev, Cheboksary, Russia \\ Email: ludmilakuznet@mail.ru
}

\section{Doi:10.5901/mjss.2015.v6n2s3p77}

\section{Abstract}

The basis of state educational policy in the National Doctrine of Education of Russian Federation plays the priority of national spiritual values that defines certain tasks in order to harmonize national and ethno-cultural relations; to preserve and support ethnic and national cultural identity, languages and cultures of Russian people. Being the link between the past and the future, ethno-cultural education promotes man of culture formation and a tolerant personality capable for ethnical self-determination, and having qualities of a citizen. The purpose of this article is to identify and justify social and pedagogical effects of schoolchildren's ethno-cultural education. The main study approaches are axiological, ethno-cultural and lingvo-culturological. The result of schoolchildren's ethno-cultural education are social (experience gaining within the international cooperation on the basis of building harmonious relations in a multicultural environment; intensification of ethnic and cultural development and selfdevelopment) and pedagogical (sustained interest and the need for ethnic and cultural values development, ethnic and cultural knowledge enrichment, developed a sense of belonging to people's history and culture; the integrity of ethnic and cultural values perception in the unity of all national art components) effects. This article may be useful for teachers developing ethnocultural educational programs.

Keywords: schoolchildrens' ethno-cultural education; social and pedagogical effects.

\section{Introduction}

\subsection{Significance of a topic}

The ongoing process of globalization as the threat of losing cultural face of the world, necessitates ethno-cultural education of young people in their homeland. Disclosure and awareness of ethnic culture's semantic features will allow Modern School to build educational process in the continuity with the best traditions of the past, will inevitably go on to establish an organic connection of goals, objectives, educational content within modern schoolchildren phenomenon (Bakhtin, 1979; Pankin, 2006; Petrova, 2014; Fyodorov, 2008). The starting point in this process is defined by humankind's cultural values, including the values that make pupil's ethno-cultural area. Adoption and adaptation of these values are characterized by cultural gains that allow us to consider them through the prism of social and pedagogical effects (Ivushkina, 2001).

\subsection{Explore Importance of the Problem}

Ethno-cultural education practicum analysis highlights the need for search and scientific substantiation of effective forms and methods to increase the efficiency of this process, review the results as they relate to social and educational effects. 
Ethno-cultural education should be organically included in the content of school subjects, which contribute to an understanding of students' ethnic and national belonging and on this basis of Russian civil identity formation, a sense of pride for their Motherland. This approach corresponds with ethno-cultural education targets - ethno-cultural and civil identification, inter-ethnic harmony in a society.

\subsection{Regional specific features}

Chuvash Republic is a multi-ethnic region presenting variety of national cultures, mentalities, and which operate on an equal basis with two official languages (Russian and Chuvash). Chuvash population comprises about $60 \%$ of people, and at the same time, there are schools with Russian, Chuvash, Tatar and Mordovian educational languages. Historically, school education's ethnic and cultural component serves the continuity with the experience of Simbirsk Chuvash teacher's school - the brainchild of I. Yakovlev, Chuvash national educator. At this school school-teachers training took into account national peculiarities of the territory, where their professional activities took place: native language lessons, artistic and aesthetic cycle lessons (music, drawing, manual labor) with implementation of their ethno-cultural component, the organization forms of extra education and leisure activities (choir, orchestra, arts and crafts, ethno-theatre activities etc.) All this aspects were aimed to preserve and revive ethnic and cultural values in rural and urban society. Effective organization of socially oriented educational process serves to Chuvash Republic schools as a model to organize ethnocultural education, the results of which should have social and educational effects.

\subsection{Status of a problem}

Significance of schoolchildren's ethno-cultural education problem should be viewed from different perspectives, since its effectiveness must be measured in terms of social and educational effects. Thus, considering the issues of ethno-cultural education, A. Pankin (2006) and T. Petrova (2014) pay special attention for the use of national pedagogical experience that reflects family's and community's needs in children's education applying the example of national ideal. G. Volkov (2009), the founder of ethno pedagogics as pedagogics branch, established a direct relation of ethno-cultural education from Pansophia of ethnopedagogics underlying interpersonal and inter-ethnic relations in society. S. Fedorova (2009) and E. Hakimov (2000) studied teacher's ethno-cultural training at high school and at teaching staff's further training. G. Atamanchuk (1997) and N. Ivushkina (2001) viewed pedagogical activity's social effects through the prism of process management that, with respect to our study, can be interpreted, as the use of ethno-cultural education in various organization forms.

\section{Methodological Framework}

Axiological, ethnocultural and lingvo-culturological approaches are the main to construct ethno-cultural educational process at school.

Axiological approach lies in the fact that ethno-cultural education is based on ethnic and cultural values perception, which are the basis for schoolchildren's humanistic and democratic value orientations. In social terms, the alignment of ethno-cultural educational process on the axiological approach basis is regarded as the most important term to harmonize inter-ethnic relations and inter-ethnic concordance in society.

Ethno-cultural approach is based on national cultural and educational environment, providing variety of activities for schoolchildren, and also forms and methods of initiation to ethnic culture. The process of training and education are based on national culture's traditions and values and are updated by the most artistically creative activities reflecting culture development in natural forms of its existence.

Lingvo-culturological approach involves the familiarization with national culture in line with the process of national language development and study because language and culture education phenomenologically make up organic "language culture" (language as a translator of culture, culture as a way of language). Therefore, familiarization with national language on artistic and imaginative basis is recognized as an effective tool in learning process, most fully realized in specially organized conditions and within national-cultural environment. 


\section{Materials and Methods}

\subsection{Study aims}

Following tasks were set during the study: 1) disclosure of essential-content characteristics of ethno-cultural education; 2) identification of socially significant and pedagogical potential of ethno-cultural education; 3) Identification and justification of social and pedagogical effects of schoolchildren's ethno-cultural education.

\subsection{Theoretical and empirical methods}

The study used a variety of complex methods, complementing each other:

- Theoretical: pedagogical analysis (general pedagogical, historical-pedagogical, ethno-pedagogical), arts, sociological literature, regulatory and legislative acts in the field of education; study and generalization of pedagogical experience, analysis and synthesis;

- Empirical: a sociological survey, interviews, discussions, study of educational activities results at secondary schools.

\section{Results}

\subsection{Essence - substantial characteristic of schoolchildren's ethno-cultural education.}

In order to disclose essence -substantial characteristics of ethno-cultural education, we presented generalized definitions of "ethnicity", "ethnic culture" concepts.

Generally ethnicity is defined as a historically constituted community of people in tribe, or national group with signs of social integrity and original behavior (Dictionary of Russian language); historically formed group of people united by common origin, language and cultural features (Guenon); group "of people speaking the same language, recognizing their common origin, possessing complex customs, way of life, stored and hallowed tradition and distinguishes it from other such groups" (S. Shirokogorov, 1923). Based on the last definition, the basis of ethnicity forms the commonness of culture - material, spiritual, artistic.

Ethnic culture is seen as a form of human activity, covering all areas of the developing ethnic group; as a set of various forms of human activity, images of self-knowledge and knowledge of the world and of its symbolic indication, which is the basis of ethnicity, thus ensuring the integrity and ability of autonomous ethnic sustainable development ( $U$. Bromley, 1983). As it follows from the above definitions, ethnic culture is the developing formation, reflecting ethnic group's cultural achievements.

Thus, there is a direct line and communication between the concepts of "ethnicity" and "ethnic culture" that is taken into account by us when determining the content of ethno-cultural education.

In this regard, ethno-cultural education is defined as education, focused on the development and socialization of ethnic identity, the preservation of its ethnic and cultural identity based on familiarization with the native language and culture. Thereby ethno-culture includes two main components: the native language and native culture.

It was important for the aims of our study to follow the principle of regionalization of education, in particular, of ethnic and cultural education. Remembering the fact that Chuvash Republic is a home for more than a hundred nationalities, there exist national language schools teaching a variety of disciplines (except Russian language courses), Chuvash, Tatar, Mordovian languages. This fact revives the problem of ethno-cultural education's social significance.

Following this fact, comes the purpose of ethno-cultural education - the formation of students' value orientations based on ethno-cultural knowledge and understanding, contributing to their ethno-cultural and civil identity and tolerance for other peoples' cultures.

Ethno-cultural education contributes to the attainment of person's ethnic and cultural status, whose parameters $\mathrm{E}$. Khakimov (2000) defined as autostereotypes, cognitive and affective components of ethnical identity; family (mother) language speaking level; interest in national holidays participation, mastering national artistic activities (crafts, handycrafts, folklore, etc.). inter-ethnic tolerance; behavior based on traditions of national etiquette (person's relation to another nationalities).

Thus, children's ethno-cultural education is considered essential for the harmonious development of a multicultural community of Russians, being a link between the past and the future. It contributes to human culture formation, a free personality able for self-determination in the world of culture, and who is considered to become a citizen. 


\subsection{Ethno-cultural potential in the context of social and pedagogical effects.}

Let's examine the potential of ethno-cultural education not only in in general but also in the context of its effectiveness, that is, in the context of emergence of social and pedagogical effects. Note that the effect (derives from Latin. Effectys execution of the action, from efficio - act, execute), is both the result and the consequence of any reasons and actions.

Previously we have identified native language and culture as main components of ethnic culture, being socially significant phenomenon. Knowledge of mother language, according to the great philosopher Hegel, is the indicator of education and culture level. However, in practice we observe that students in bilingual school, which is widespread in multinational Russia, in fact, study mother language as not their own, but as a foreign, being apart from its figurative nature. This fact is indicated and underlined by practicing teachers and methodologists. The realities of our life also suggest that social tensions often arise based on prejudice or imposing not their own, but another language. To change this practice of studying student's maternal language or the language of the place where he lives, is highly possible if this approach will be based on ethno-cultural teaching aspect, that is, the integration of artistic culture into Chuvash language lessons.

Our study confirms the hypothesis that if one starts studying Chuvash language from perceiving its intonation architectonic, that is, with "the music of a language ", and this is possible when Chuvash folk songs is played in Chuvash language (imagine performing Russian folk song "In The Meadow Stood a Little Birch Tree" "in other language, for example, in English, children immediately start saying that the song sounds as a non-Russian), the interest for the language will be vivid: because it will turn out to be melodious. In addition, if you integrate the new words sounding into play activities, they are perceived naturally and easily. Thus, the song and the game as ethno-cultural phenomenon being parts of ethnic culture, organically included into the educational process, contribute to the formation of stable interest to the language, which is an ethnical culture's grain.

Ethno-cultural education is being applied during music and art courses, culture of a native land courses, and in various forms of additional education and leisure activities of students, it also has a didactic and educational potentials, which constitute abilities to:

- formation of moral-aesthetic attitude real life within students;

- development of a creative personality based on an understanding of Chuvash folk art's national features and artistic interpretation of its ethnic culture examples;

- schoolchildren's understanding of folk art's universal, humanistic nature, especially through fairy tales, legends, songs, rituals, and on this basis, development of schoolchildren's tolerance.

- We identified the following pedagogical provisions to reach these aims:

- to create cultural, aesthetic and moral settings during the lessons;

- to develop student's active and practical attitude towards folk art;

- to include artistic activities into each student's lesson;

- to include authentic (genuine) folk art, especially songs, embroidery, folk costumes during the lessons;

- to involve parents into the process of traditional artistic culture development of Chuvash people.

These provisions determine pedagogical effect of ethno-cultural education, reflected in the fact that children through the familiarization with the ethnic and cultural values generated a strong interest to their own and another culture, to the beauty and sonority of native or other language; they also develop a sense of respect for the language as cultural wealth of people, adhesiveness required to perceive ethnic culture samples reflecting particular and panhuman, ethnocultural historical parallels; they also expand cultural horizons. Social effect is determined by the community's growing interest to the national culture and its basis - the language, the feeling of a person of any nationality a psychological comfort, increasing tolerance attitudes and behavior within the society.

\subsection{Socio-cultural orientation of educational activities at Simbirsk Chuvash teacher's school.}

Eethno cultural education's socio-cultural orientation is defined as a process aimed at the students' active involvement in socially useful activity by means of national art, which is approved and evaluated by the whole society.

Let us start revising social and pedagogical effects of ethno-cultural education at modern school by the brilliant representation of ethno-cultural experience implementation at Simbirsk Chuvash teacher's school, established in 1869, directed for more than 50 years by educator in Volga region - Ivan Yakovlevich Yakovlev. At this time, school's prime activity was socio-cultural orientation of students' art education, involving their active participation in socio-oriented activity, which has been highly valued by the communities at Simbirsk and Nizhny Novgorod.

We have identified socio-cultural orientation's social and educational effects of educational process at Simbirsk 
Chuvash teacher's school, which are reflected in following achievements:

1. Famous concert programs at Simbirsk. Simbirsk scientific archive commission offered to arrange a Chuvash song concert, which took place in January 19, 1909, all the items were full on "encore." Folk music collected during the expedition of 1902, in 1909 had been published a by Yakovlev under the name "Chuvash folk songs tunes and texts to them" (Part 1). When opening school at Large-Arabusinskaya village within Buinsk district in October 1, 1897 school choir's first performance took place (organized and supervised by graduate M. Danilov). This school choir performed as well at the National Exhibition in Nizhny Novgorod in 1896. Main opera scenes of M. Glinka's "Life for the Tsar" ("Ivan Susanin") were staged at Simbirsk in 1913.

2. N. Nekrasov's pictures on Chuvash themes were exhibited in Moscow and international exhibitions. The teacher Myron Timophey organized painting lessons at Ishakovskaya Chuvash teacher's school. A secondary school teacher N. Superanskiy arranged molding lessons at Yadrinskaya girls' school: his students entered Kazan art school afterwards.

3. Arts and crafts training was organized at Bichurinskaya, Alikovskaya, Hochashevskaya two-year schools and some others. Their importance cannot be overestimated: natives from Yakovlev's school, already being national teachers, recreated ancient folk crafts on professional level. Furniture samples: tables, cabinets, chairs were displayed at exhibitions in Kazan, Simbirsk, Nizhny Novgorod, Moscow. For this tremendous work, the school was awarded with the gold medal in 1896. Purely pedagogical value of manual labor Yakovlev expressed in the following words: "The appointment of manual labor is to develop manual smartness, visual estimation and elegant taste."

4. Traditional folk festival Akatui "with dances, Chuvash folk games, contests, with girls presenting embroidered shawls was a great event for Simbirsk, it also was a vivid demonstration of spiritual and artistic culture samples of people that tightened together Russian city's multicultural environment where Chuvash people live.

5. Textbooks, spelling- books, Russian poets and writers translations had been published by own strengths. $\mathrm{K}$. Ivanov had particularly distinguished at translation work. Such ethno-cultural education organization has facilitated to Simbirsk Chuvash teacher's school to become a real center of Chuvash people spiritual culture, and to formation of professional art of Chuvashia (Kuznetsova, 2014).

Socio-cultural orientation ethno-cultural education is defined as a process aimed at actively including them in socially useful activity, by means of art, approved and evaluated by society.

\subsection{Social and pedagogical effects of schoolchildren's ethno-cultural education at Chuvash Republic}

The effectiveness of ethno-cultural education can be measured, first of all, by the effects on the student's environment, the way it changes it to the enrichment with ethno-cultural values, and secondly, it can also be measured by student's new acquiring in the personal and cultural-educational spheres. All this aspects can be reflected in the emergence of social and pedagogical effects.

As scientists understand, "social effect" related to effect in society, firstly, it's a unique tool for creating "favorable conditions for the full development of the individual, the ability for citizens to apply their creative powers and abilities, which ... is reflected in hard physical labor reduction, an increase in free time, material and cultural improvement of living standard and health protection"(Ivushkina, 2001). Secondly, scientists understand this social effect as a result received by the society performing a certain kind of work, and as a source or tool to develop society as the main link in the chain of continuous reproduction of social life (Atamanchuk, 1971).

The experience of Tsyvilsk Secondary School №2 confirms the second fact, namely, implementing school program " Lets preserve our national traditions " children had been actively involved in artistic activities, entering a society, enriching it with new creativities (exhibitions, concerts, volunteer action and charity, creation of artistic works (products), interior appointments and aesthetic design environment), which are based on aesthetics and artistic taste. During such activities, children created themselves an ethno-cultural space, the cultural soil that nourishes their implementation of creative ideas for social projects.

The result -the social effect- out of this activity was the growing interest of parents and adults to folk festivals, traditional crafts, their appearance among the participants of Chuvash arts and crafts school exhibitions (embroidery, wood carving, patterned weaving, felting etc.) Moreover, grandmother and great-grandmother started bringing to school vintage designs of utilitarian objects, Chuvash embroidery samples on shirts, headband (Masmak), headbands (Surban) and towels. National holidays' moral potential held in the school with their parents could not be overestimated: thanks to parents and adults initiative family competitions started taking place, as well as exhibitions and calendar holidays from cultural traditions of Russian, Chuvash, Tatars. 
We found a definite pattern during the study: the specific ethno-cultural education not always and not necessarily reflects in the form of social or pedagogical effect. The results had been confirmed by a survey conducted at schoolchildren's secondary school № 62 in Cheboksary named as "a student's attitude to Chuvash language study." This survey (152 participants among pupil) among pupil of 1-4 and 5-8 grades showed the following: $80 \%$ of students in grades 1-4 showed profound interest in Chuvash language study; 5-8 classes were slightly less interested - 70\% of pupil, $60 \%$ in 5-8 grades gave answers showing their civic and patriotic position. These results prove the correctness of ethnocultural approach to Chuvash language study, since for many pupil Chuvash is a non-native language, the fact that school is implementing a program "Integration of Chuvash art culture and language at elementary school."

This example shows that language is as a part of culture, and its learning is reflected in social and pedagogical (educational) effects: upbringing language culture, yielding pupil as active citizens, brining feeling of love for their motherland and national tolerance.

\section{Discussions}

Ethno-cultural education problems are considered in works of T.N. Petrova (2014), S.N. Fedorova (2008), E.R. Khakimov (2000) and others. They emphasize the need to introduce ethnic culture during learning process, to educate and create national-cultural education and multicultural environment, providing functionally students' activities with a variety of forms and methods in order to get familiar with their national culture. It is in a unity on an equal basis that national culture, introduced in educational process, contributes to the harmonization of interpersonal and inter-ethnic relations. However, their works do not consider the impact of ethno-cultural education through the prism of social and educational effects, which is a subject of our study.

\section{Conclusion}

If we underline the socio-cultural continuity of experience at ethno-cultural educational process at Simbirsk Chuvash teachers' school having modern teaching practices, with the perspectives of ethno-cultural education at modern schools, we can define several aspects:

- Orientation on practice within artistic education, (creation of exhibition samples, souvenirs and other applied purposes);

- Creation of the atmosphere perception of spiritual and artistic values of pupil in class through the integration of different art and folk art types (music, oral literature, ethnic performances, folk games and dances, handicrafts, traditional costume);

- students' and teachers' joint activities aimed to create and enrich artistic environment at school and in the surrounding society;

- exhibitions and concerts organization, volunteer and charity shares, creation of artistic works (products) in the interior appointments and aesthetic design environment, which are based on aesthetics and artistic taste.

- Thus, our research has allowed us to consider social effects as a result of modern ethno-cultural education, they are reflected at different levels:

- level of general education among schoolchildren at school society and at family level. At the level of education among schoolchildren, the main social effect is obtained because of ethnic and cultural education. It is meant to develop the individual as a human of culture, the ethno-cultural knowledge volume and the ethnic and cultural activities experience contribute to the development of an independent position within human of culture (national, universal);

- At school society level - school environment improvement (educational, subject, informational); ethnic and cultural development intensification and student's self-development; increasing number of students involved in different kinds of events and activities, clubs, and ethnic and cultural spheres;

- At family level - an ethno-cultural family's socialization (the feeling of kinship, native language speaking level, having family traditions, and others).

Pedagogical effects from ethno-cultural education are characterized by the fact that pupil: start forming a stable interest and need for the development of ethnic and cultural values; accumulate baggage of ethno-cultural knowledge; develop a sense of belonging to the history and culture of their people; skills to perceive ethnic and cultural values are developed in the unity of all folk art components; develop associative thinking based on the perception of artistic samples of folk art in triad format: "word-music-pattern"; creative consistency is formed as a sustainable creative attitude willing to express themselves in a creative work; develop artistic taste, sense of beauty, based on national ideals. 


\section{References}

Atamanchuk G.V., 1997. The theory of a State government. Moscow: The Legal literature.

Bakhtin M.M, 1989. Aesthetics of verbal creativity. Moscow: Art.

Bromley V., 1983. Essays on the theory of ethnos. Moscow: Science.

Fedorova S., 2008. A systematic approach to ethno-cultural training of future teachers. Yoshkar-Ola, Mari State University.

Ivushkina N.V., 2001. Social effect of investment processes. PhD Thesis. Moscow.

Khakimov E.R., 2000. Personality's ethnic identity its impact on the professional work of a teacher. PhD Thesis. Kazan.

Kuznetsov L., 2014. National cultural learning environment of a student. Cheboksary: Chuvash State Pedagogical University.

Pankin A.B., 2006. Formation ethno-cultural personality. Textbook for students of higher educational institutions. Moscow: SAG.

Petrova T.N, Petrova L.V., 2014. The basis cultural-historical and spiritual-moral education as a strategic factor of modern education. «The recommended International Congress in Social Sciences and Humanities». Proceedings of the Congress (19 May 2014). «East West» Association for Advanced Studies and Higher Education GmbH. Vienna.

Sulima I., 2010. Environmental approach as the methodology of scientific and pedagogical research. Bulletin of high school. Wolves G.N., 2009. Ethno-pedagogical Pansophia. Elista: Kalmyk State University. 